\title{
Antimicrobials in Boar Semen Extenders - A Risk/Benefit Analysis Morrell JM*
}

Clinical Sciences, Swedish University of Agricultural Sciences, Uppsala, Sweden

\begin{abstract}
Antimicrobial agents are added to semen extenders to control the growth of microbes contaminating semen during collection. However, such a non-therapeutic use of antibiotics is not without problems, since it may contribute to the development of antibiotic resistance. This review analyses the risks and benefits of using antibiotics to control bacteria in boar semen extenders, including understanding how semen becomes contaminated and the effects of these contaminants on sperm quality. In addition, the advantages and disadvantages of using antibiotics to control bacteria will be considered, as well as possible alternatives.
\end{abstract}

\section{How do Samples become Contaminated and with What?}

Boar semen is usually collected by the gloved hand method, allowing possibilities for bacterial contamination during the collection process as well as during the subsequent processing of the semen. Bacteria such as Staphylococcus and Streptococcus spp., are found on the skin and mucosa of health animals as well as in the gut (e.g. enteric bacteria) and respiratory tract [1]. Personnel also represent a source of contamination for the semen. Moreover, environmental bacteria are found on surfaces and in the air in the processing laboratory, as well as in water for washing equipment, originating from water tanks and pipes.

\section{Effects of Bacteria on Sperm Quality}

The presence of bacteria in extended semen creates competition for nutrients [2] and also results in the production of metabolic byproducts that may harm the spermatozoa. In addition, some bacteria contain lipopolysaccharides (LPS) in their cell walls which are released when they die; these LPS also cause damage to spermatozoa. The presence of contaminant bacteria in extended boar semen is associated with a decrease in sperm motility and viability [3,4], premature acrosome reaction [5] or sperm agglutination [6]. Furthermore, bacteria may cause the production of antibodies directed against the sperm glycocalix complex $[7,8]$.

\section{Why Should this be a Problem for the Female?}

Since bacteria are transferred to the female reproductive tract during natural mating, several physiological mechanisms have developed to protect the female. Thus surplus semen is removed from the uterus via backflow and various immune mechanisms are activated to attack and remove bacteria before the arrival of the embryo in the uterus for implantation. The problem arises when stored semen is used (as is very common in the pig breeding industry), because the semen extenders used to maintain sperm viability and functionality also serve as nutrient media for bacterial growth. Moreover, conventional storage of extended boar semen at $16-18^{\circ} \mathrm{C}$ allows for some bacterial multiplication since the temperature is not sufficiently low to prevent growth [2]. Thus inseminating a stored semen dose may result in a higher bacterial load being deposited in the uterus than would be the case in natural mating. The insemination of sows with contaminated semen may be associated with vulvar discharge and returns to oestrus [9], or embryonic or foetal death, endometritis, systemic infection and/or disease in recipient female [1], or reduced litter size [10]. Deteriorating sperm motility and membrane integrity was associated with increasing bacterial loads [11].

\section{Addition of Antibiotics to Semen Extenders}

Bacterial contamination can be controlled by adding antibiotics to semen extenders. The antibiotics used and the concentrations recommended for commercial semen doses are stipulated by national and international guidelines [12]. However, there are disadvantages to this practice, both for sperm quality and for the environment. The antimicrobials may themselves have a detrimental effect on sperm survival, thus limiting the choice of agents that can be added to semen extenders. In an effort to reduce this toxicity, a cocktail of broad spectrum, highly potent antibacterial agents are used. However, any use of antibiotics can contribute to the development of antibiotic resistance, and this resistance can, in turn, be transferred to other bacteria in other host species [13]. Thus, unfortunately, even though combinations of antibiotics may reduce sperm toxicity, they may actually contribute more to antibiotic resistance than single agents. It is essential that any extender containing antibiotics and any unused semen doses should be disposed of in an approved manner that results in the inactivation of the antibiotics before they reach the environment.

\section{Risk/Benefit Analysis}

Risk/Benefit analysis is given in Table 1.

\begin{tabular}{|c|c|c|}
\hline $\begin{array}{c}\text { No } \\
\text { antibiotics }\end{array}$ & $\begin{array}{c}\text { Risk } \\
\text { Batrients in semen extender, produce } \\
\text { toxic byproducts and LPS; may cause } \\
\text { disease in females after Al. }\end{array}$ & $\begin{array}{c}\text { Benefit } \\
\text { spermatozibiotic toxicity to } \\
\text { contributing to the spread } \\
\text { of antibiotic resistance }\end{array}$ \\
\hline Antibiotics & $\begin{array}{c}\text { May be toxic to spermatozoa; bacteria } \\
\text { found in semen may be resistant to the } \\
\text { antibiotics; can lead to contamination } \\
\text { of the environment; may lead to the } \\
\text { development of antibiotic resistance; can } \\
\text { release LPS. }\end{array}$ & $\begin{array}{c}\text { Kill contaminating bacteria } \\
\text { before they have a chance } \\
\text { to grow or compete } \\
\text { for nutrients in semen } \\
\text { extender; bacteria are not } \\
\text { transferred to the female } \\
\text { via Al (unless resistant), }\end{array}$ \\
\hline
\end{tabular}

Table 1: Risk/Benefit analysis.

${ }^{*}$ Corresponding author: Jane M Morrell, Clinical Sciences, Swedish University of Agricultural Sciences (SLU), Box 7054, SE.75007, Uppsala, Sweden, E-mail: jane.morrell@slu.se

Received January 27, 2016; Accepted February 15, 2016; Published February 25,2016

Citation: Morrell JM (2016) Antimicrobials in Boar Semen Extenders - A Risk/ Benefit Analysis. J Antimicro 2: 107. doi:10.4172/2472-1212.1000107

Copyright: @ 2016 Morrell JM. This is an open-access article distributed under the terms of the Creative Commons Attribution License, which permits unrestricted use, distribution, and reproduction in any medium, provided the original author and source are credited. 


\section{Non-antibacterial Methods of Controlling Bacterial Contamination}

Strict attention to hygiene during semen collection and processing may reduce bacterial contamination [3]. The normal flora of the skin, hair and respiratory tract of the male cannot be reduced: however, personnel can minimise their own contribution through personal hygiene and the sterility of the collection equipment. Protective clothing and footwear should always be worn; it should be laundered regularly or disinfected as appropriate. Personnel with respiratory infections should preferably avoid collecting semen or should wear disposable masks. The semen collection area and equipment should be thoroughly cleaned and disinfected. However, since soaps and disinfectants can be spermicidal, residues of these substances should be avoided on surfaces that will be in contact with semen. Local practice regarding cleanliness and hygiene should be followed at all times. The use of closed semen collection devices will help to prevent contamination from the environment.

These measures will certainly reduce bacterial contamination but will not remove it completely. Physical removal of the bacteria from sperm samples, e.g. by colloid centrifugation [14,15], could be an effective alternative to adding antibiotics to semen extenders. In the reported studies, separation of spermatozoa and bacteria was more effective for some bacteria than others, depending on whether the bacteria possessed a flagellum or could attach to the spermatozoa, but also on their size and whether they could aggregate or swarm. Another determining factor appeared to be whether the colloid centrifugation was carried out immediately after semen collection or after several hours of storage. Interestingly there was some indication that bacteria that had succeeded in passing through the colloid into the sperm pellet might show reduced ability to multiply, despite the lack of antibiotics in the colloid formulation. This is an interesting observation and is in keeping with other studies on pasture contamination with faecal bacteria where it was seen that bacteria that have bound to soil particles are unable to grow. The possibility that the colloid formulation may act as a natural bacterial inhibitor warrants further investigation.

Although this review focuses on extenders for boar semen, the same principles apply to other species too, although in other species e.g. bull, the use of frozen semen may reduce the opportunities for bacterial multiplication in semen doses. Therefore, efforts to improve cryopreservation methods for boar semen to give comparable fertility results to stored semen, might also contribute to a reduction in antibiotic usage. Alternatively, the development of cold storage methods for boar semen instead of the conventional storage at 16 to $18^{\circ} \mathrm{C}$ could reduce bacterial multiplication and therefore reduce antibiotic usage.

\section{References}

1. Maes D, Nauwynck H, Rijsselaere T, Mateusen B, Vyt P, et al. (2008) Diseases in swine transmitted by artificial insemination: an overview. Theriogenology 70 : 1337-1345.

2. Althouse GC (2008) Sanitary Procedures for the Production of Extended Semen. Reprod Dom Anim 43: 374-378.

3. Althouse GC, Pierdon MS, Lu KG (2008) Thermotemporal dynamics of contaminant bacteria and antimicrobials in extended porcine semen. Theriogenology 70: 1317-1323.

4. Bussalleu E, Yeste M, Sepúlveda L, Torner E, Pinart E, et al. (2011) Effects of different concentrations of enterotoxigenic and verotoxigenic $E$. coli on boar sperm quality. Anim. Reprod. Sci 127: 176-182.

5. Köhn FM, Erdmann I, Oeda T, el Mulla KF, Schiefer HG, et al. (1998) Influence of urogenital infections on sperm functions. Andrologia 30: 73-80.

6. Monga M, Roberts JA (1994) Spermagglutination by bacteria: receptor-specific interactions. J. Androl 15: 151-156.

7. Auroux MR, Jacques L, Mathieu D (1991) Is the sperm bacterial ratio a determining factor in impairment of sperm motility: an in-vitro study in man with Escherichia coli. Int J Androl 47: 264-270.

8. Kurpisz M, Alexander NJ (1995) Carbohydrate moieties on sperm surface: physiological relevance. Fertil. Steril 63: 158-165.

9. Althouse G, Kuster C, Clark S, Weisiger R (2000) Field investigations of bacterial contaminants and their effects on extended porcine semen. Theriogenology 53 : 1167-1176.

10. Maroto Martín LO, Muñoz EC, De Cupere F, Van Driessche E, EchemendiaBlanco D, et al. (2010) Bacterial contamination of boar semen affects the litter size. Anim Reprod Sci 120: 95-104

11. Sepúlveda L, Bussalleu E, Yeste M, Bonet S (2014) Effects of different concentrations of Pseudomonas aeruginosa on boar sperm quality. Anim Reprod Sci 150: 96-106.

12. (2014) Council Directive, European Union, 90/429/EEC

13. Johansson A, Greko C, Engström BE, Karlsson M (2004) Antimicrobial susceptibility of Swedish, Norwegian and Danish isolates of Clostridium perfringens from poultry, and distribution of tetracycline resistance genes. Vet Microbiol 99: 251-257.

14. Morrell JM, Wallgren M (2011) Removal of bacteria from boar ejaculates by Single Layer Centrifugation can reduce the use of antibiotics in semen extenders. Anim Reprod Sci 123: 64-69.

15. Morrell JM, Klein C, Lundeheim N, Erol E, Troedsson MH (2014) Removal of bacteria from stallion semen by colloid centrifugation. Anim Reprod Sci 145 47-53. 